Article

\title{
Critique, Creativity and the Co-Optation of the Urban: A Case of Blind Fields and Vague Spaces in Lefebvre, Copenhagen and Current Perceptions of the Urban
}

\author{
Jan Lilliendahl Larsen ${ }^{1, *}$ and Jens Brandt ${ }^{2}$ \\ ${ }^{1}$ Supertanker, 2300 Copenhagen, Denmark; E-Mail: jan@supertanker.info \\ 2 School of Architecture, Tampere University of Technology, Tampere, 33720, Finland; E-Mail: jens.brandt@tut.fi \\ * Corresponding author
}

Submitted: 30 January 2018 | Accepted: 23 April 2018 | Published: 12 June 2018

\begin{abstract}
Even though more than four decades have passed since the writing of The Production of Space, with walls, governance regimes and financial markets coming tumbling down, cities around the globe still find themselves in-and reproduce what Lefebvre would characterize as-abstract space, a space produced by economy and bureaucracy, and reproducing dominant regimes thereof beyond the grasp of users and inhabitants of cities. In this article, it is argued that an urban perception is cancelled out in the reductive struggle between two dominant perceptions of urban change. The article unfolds in three moments: firstly, an outline of Henri Lefebvre's critique of 'the urban' and 'the production of space' is presented in order to clarify his critique of reductive perceptions and the significance of the urban in his work; secondly, a conceptualizing narrative anchoring Lefebvre's concepts to recent developments in Copenhagen, not least developments related to the sub-cultures, is explored - showing how different agents pursue the realization of different perceptions of urban change; thirdly, it is concluded that this development needs to be conceptualized as a reduction of the urban into a residual as well as the unfolding of a dominant contradiction between 'critique' and 'creativity'.
\end{abstract}

\section{Keywords}

centralities; creative cities; critique of neo-liberalism; diversion; Henri Lefebvre; reduction; the urban; transduction; urban change; vague space

\section{Issue}

This article is part of the issue "Urban Planning and the Spatial Ideas of Henri Lefebvre", edited by Michael E. Leary-Owhin (London South Bank University, UK).

(C) 2018 by the authors; licensee Cogitatio (Lisbon, Portugal). This article is licensed under a Creative Commons Attribution 4.0 International License (CC BY).

We focus attentively on the new field, the urban, but we see it with eyes, with concepts, that were shaped by the practices and theories of industrialization, [which] is therefore reductive of the emerging reality. (Lefebvre, 2003a, p. 29, italics in original)

\section{Introduction}

In Copenhagen folklore, Krøyer's Place (Krøyers Plads) is, first of all, synonymous with a high profile antagonistic process regarding a high-rise proposal for a centrally located waterfront site in 2003. It sent the local polity into a state of emergency in the following years and turned the site into a sleeping Beauty for more than a decade (Koefoed, 2017; Larsen, 2007).

If one looks a bit closer today, as the site has finally been developed, it seems to confirm currently dominant perceptions of urban change, that is, both 'creative' perceptions within planning practice and theory and critiques hereof within academia and the activist underground. A former, proud and bustling place of maritime industry and commerce developed through centuries is laid waste by a general process of post-industrialization, lies dormant for decades, is temporarily used by creative entrepreneurs, who develop the property culturally, while developing themselves and their endeavor 
into economically viable enterprises, after which the creative scene moves on to another post-industrialized space, leaving yet another inevitably gentrified piece of real estate in the booming property jig saw of the city as luxury housing for the urban consumer. Whether perceiving it as an eventually successful attempt at realizing a dream of Copenhagen as cool and creative or as an urbanization of injustice, the case seems to be closed. The result is given and, by default, so is the complex, historical process, which leads up to it. Or is it?

Underneath all functionalist reductions that perceive history as a straight line in the light of a realized present, a plethora of possibilities of something else unfolded in the vague space and opened for different futures, only later to collapse in a Juggernaut of a process en route towards its inevitable conclusion. So, in fact, apart from signifying urban antagonism, entrepreneurial waterfront redevelopment and creative gentrification, Krøyer's Place is also a signifier for other perceptions of urban change, partly developed through the workings of an informal, urban laboratory: Supertanker. The laboratory-which the authors were founding members of-lives on today through the practices, experiences and concepts that molded each other into the vague premonitions of a reinvented Copenhagen urbanity. By reconsidering the development of Krøyer's Place, not least in the founding years of 'creative Copenhagen' (the long decade from the mid90 s to the late 2000s), it is attempted in this article to "unconceal" (Lehtovuori, 2005, p. 114) this take on its history and, in so doing, articulate another perception of urban change, which harbors political and cultural possibilities currently excluded and reduced by dominant perceptions, that is, those of creativity and critique.

This re-imagination of unrealized but possible futures is impossible without-has, in fact, only been possible with-the constant, transductive (a concept of an alternative form of reasoning which will be clarified below) articulation, within a combined methodology of participant observation and action research, between practices, experiences and concepts guided by the urban philosophy of Henri Lefebvre. Lefebvre's influence on current perceptions of the city and urban change is broadly recognized today, paradoxically within both creative and critical perceptions of urban change. However, it is less recognized that Lefebvre's strenuous relation with dogmatism in all its shapes and colors (religious, philosophical, capitalist, Stalinist, 'cybernanthropic', structuralist and Marxist) had deep implications for his critique-and thus, also, for his enrollment under the banner of current Marxist critique. In fact, his urban thought has always had an ambivalent relationship with contemporaneous Marxist critique-famously exemplified with his feud with the structuralist Marxism of Manuel Castells in the 70s, but also replicated in the current reception of his ideas.

Therefore, in order to re-imagine the history of Krøyer's Place through Lefebvre's theories of the urban and social space, we also need to untangle Lefebvre's critique from a current (orthodox) Marxist habit of snub- bing the urban as well as unorthodox interpretations of Lefebvre with mantras such as 'remember Lefebvre was a Marxist'. The sheer dogmatic and petrifying force of such "blind" (Lefebvre, 2003a, p. 29) statements-that conveniently bypass Lefebvre's explicit reference to the thoughts of traditional adversaries of Marx in studying and producing modernity such as Hegel and Nietzsche (Lefebvre, 2003b)-is a major theoretical constraint in endeavors into the exploration of new, locally sensitive and timely critiques of urban development; a constraint comparable to the discursive might of local policynetworks in everyday urban practice.

The argument of this article thus unfolds in the following three moments. Firstly, an outline of Henri Lefebvre's critique of 'everyday life', 'urbanization' and the 'production of space' is presented in order to lay the ground. The guiding thread in his ongoing conceptualization is found in the broadly defined productive relation between 'man', society and nature, which gradually unfolds through his different works. Apart from being a critique of narrow and abstract, economicist or bureaucratic perceptions and practices of social space, Lefebvre's focus is the possibilities of an urban alternative to these. An essential moment of his critique is his perception of citizens constantly attempting to realize these possibilities in the crevices of 'vacant spaces' (or rather 'vague spaces, as further conceptualized by Larsen, 2014) far away from the centralities underpinning abstract space. The pivotal, ambiguous, and therefore open role of his concept of 'diversion' is underlined.

Secondly, we disclose a conceptualizing narrative anchoring Lefebvre's concepts to recent developments in Copenhagen. We show how different agents, in a crisisridden city, pursue the realization of different perceptions of urban change, where change is most necessary as well as possible, in the vague spaces of the city. The narrative runs more or less in the form of a one-way domination according to values and representations in a creative discourse working according to the neo-liberalizing policy-networks of the city. Today, of course, this is almost stating the obvious, both regarding the developments in Copenhagen and a host of other cities. However, through Lefebvre's concepts, other perceptions of this process are possible.

We conclude, thirdly, by arguing that the development also has to be conceptualized as a reduction of the urban (that is, the reduction of the urban possibilities related to the diversion of vague spaces) through the workings of the urban industry of real estate interests, planning policies, consultants and academia as well as the informal cultures of the city within a dominant contradiction between creativity and its critique.

In this way, the presentation of the urbanization process taking place in those pivotal, ambiguous spaces of Copenhagen, the vague spaces, supplement established, critical narratives of post-industrial Copenhagenregarding the early (Lund Hansen, Andersen, \& Clark, 2001) and intermediate (Bayliss, 2007) phases of the pro- 
duction of 'creative Copenhagen' and the waterfront redevelopment in a neo-liberalized context (Desfor \& Jørgensen, 2004)-with a subcultural and urban perspective. While practically co-opted, the development of these spaces also end up relativizing the dominant contradiction according to the urban potentials of these constantly generated, informal centralities of the city-and the reductive nature of the dominant discourses vis-à-vis the urban and Lefebvre will be demonstrated.

\section{Lefebvre on the Productive Significance of the Urban}

\subsection{From 'The Production of Man' To 'The Production of Space'}

From his earliest vantage point in a Hegelian interpretation of Karl Marx, Lefebvre's focus has been the contradictory process of what he, in an essential chapter in Dialectical Materialism (Lefebvre, 2009a), characterizes as 'the production of man', that is, the productive interaction with nature in which man both produces a second nature and produces himself in the process. 'Production' is Lefebvre's core concept, his 'concrete universal', from which he conceptualizes development as an increase in differentiation, contradiction and transcendence. So, the basic contradiction between man and nature is initially 'transcended' in production and its products (second nature and appropriated, total man)-only for new contradictions to arise as the second nature of the social world, with its ever more abstract division of labor and capitalist extraction of surplus value, falls back on man as a dominating power. It follows from this that the currently basic contradiction is the alienating effect (that is, the lack of appropriation of human nature in production or of man's recognition of himself in the product and his peers) within the capitalist mode of production on the human endeavor of appropriating internal and external nature, and that this contradiction is transcended through greater control or domination of nature and the social world.

By integrating the focus on appropriation of nature and alienation of man in the critique of the capitalist mode of production, Lefebvre challenged the Marxist orthodoxy of the 1930s and 1940s. The challenge was incarnated in his Hegelian concept of production, which from the outset was broader than the reductive focus on one aspect, that is, economic production. This aspect of production he conceptualized as the external domination of nature, whereas the internal appropriation of man was pushed ever more into the 'underdeveloped' and 'lagging' sphere of everyday life (Lefebvre, 1991a). He subsequently moved into this sphere in order to broaden both the scope and the form of Marxist critique. In perceiving everyday life as an unnoticed "residual" (Lefebvre, 1991a, p. 86) in the reductive conceptualization of orthodox Marxism, he relativized the relentless workings of the conceptual and practical dialectic of Hegel and Marx. Even the most rational conceptualizations leave something out of sight, which needs to be understood, recognized and thus reintegrated in a balanced social critique. In a culture where the technical domination of nature (and, hence, the alienation of man) prevails (with orthodox as well as Hegelian Marxism being complicit), the residuals hidden within the sphere of everyday life are, among others, the 'lived', the immediate experience of the world, and poiesis, the creative appropriation rather than technical domination of internal and external nature (Lefebvre, 1991a, p. 86, 2016, p. 12).

With these residuals, Lefebvre pursued his study of the productive dialectic between man and nature, firstly in the archaic rituals, landscapes and everyday lives of rural France and later in the gradually larger, urbanized areas. Thus, he saw the city and urbanization as a basic moment of differentiation of production, and therefore also as a relation of contradiction. In its varying, historical forms it is both one of the most important poietic oeuvres created through history (Lefebvre, 2016, p. 9) and the frontline of technical domination due to industrial urbanization (Lefebvre, 1995, 1996, 2003a). He developed a basic conception of the 'urban form' as encounter, assembly and simultaneity, which per definition entailed conflicts and contradictions-and necessitated the ability to develop ways to handle and transcend them (Lefebvre, 1996, p. 75). While basically structured by cores of centrality, he described the industrial form of urbanization as the explosive "penetration" into the countryside of "a movement of concentration" through a larger and "increasingly tight" (Lefebvre, 1996, pp. 71-72) urban fabric of infrastructural networks and, with it, an urban society with its own systems of objects, values and more intense life. Within the urban, the contradiction between domination and appropriation was conceptually molded into the gradually more tense contradiction between the "far order" of the state and economy, increasingly concentrated, or imploding, in the refurbished, old centralities, and the "near order" of the community, the village and everyday life (Lefebvre, 1996, p. 71). So, as this explosion-implosion of the urban unfolds, urban centrality came down to the accumulation of power and capital, while significant parts of the near order of citizens were excluded from the continued creation of the oeuvre of the city, now reduced to a product (meaning a serially reproducible thing). It was in this context that he called for "the right to the city" as a right of citizens to appropriate themselves by participating in the creation of the city as a collective oeuvre (Lefebvre, 1996, p. 71).

As the urbanization process gathers further pace during the 1960s, Lefebvre's conceptualization follows suit. He perceives an industrial urbanization process that not only goes ever deeper to the core of lived everyday life, but also spans larger and larger geographical areas of the globe. The local depth and geographical scope of modern urbanization, a process that Lefebvre characterizes as planetary, leads him to yet another leap in his unorthodox Marxism. Urbanization is not only a pivotal secondary circuit of surplus capital spilling over from the primary circuit (the production and consumption of goods 
and commodities) into the real estate of cities (Lefebvre, 2003a, p. 159). It is also through this planetary urbanization process that capitalism survives its own crisis prone destiny. Due to this practical circumstance and the theoretical crises concerning fragmented, abstract and industrial conceptions of the city and society, which inhibit the understanding of the depth and scope of this urban problematic (i.e., the understanding of the city in state planning as an aggregation of abstract functions and circulation of things; see, Lefebvre, 2003a, p. 29), Lefebvre adopts the concept of space. Furthering his reconceptualization of the Marxist concept of production, he thus states that it is through the 'production of space' that capitalism survives. This is where the circle closes, the critique of Marxism and modern society working within Lefebvre's thesis of 'the production of man' has been contextualized in relation to late-modern urbanization processes within his thesis of 'the production of space'.

\subsection{Pursuing the Urban in the Crevices of Abstract Space}

In conceiving 'the production of space' as a leap in the productive forces (Lefebvre, 1991b, p. 103), Lefebvre transcends the Marxist critique of the labor process within the capitalist mode of production accordingly. Lefebvre elaborates the critique of abstract labor (the concrete act of productive labor defined reductively along the lines of exchange value; see, Stanek, 2008) into a critique of the production of abstract space: social space as 'concrete abstraction', that is, reductively conceived and produced along the lines of state planning and exchange value, as a homogenous and fragmentary product that dominates man in return by making him a mimetic product (Lefebvre, 1991b, p. 376) of the play of abstract and floating signifiers instead of a poietic oeuvre of his own appropriative practice.

As in his first major theoretical endeavor into Marxism, he directs his critique of abstraction towards both socialist and capitalist modes of thought and production; both of them imprisoned by signifiers produced in and reproducing the industrial epoch and thus blind towards the urban (Lefebvre, 2003a, p. 29), towards a new mode of production, which, according to Lefebvre, is neither capitalist nor socialist, but "the collective management of space" (Lefebvre, 1991b, p. 103). To enable (the perception of) this mode of production, Lefebvre calls for a transductive rather than an inductive or deductive theory and practice. Rather than turning "fact into law" (induction) or going from "affirmation to implication" (deduction), Lefebvre calls for a move "from the (given) real to the possible" (Lefebvre, 2002, p. 117) via "the construction of virtual objects" (Lefebvre, 1976, p. 55), critiquing and moving away from abstract conceptions and concrete abstractions "toward the concrete...to a practice, urban practice, that is finally or newly comprehended" (Lefebvre, 2003a, p. 5, original emphasis), where "theoretical concept and practical reality [is] in indissoluble conjunction" (Lefebvre, 1991b, p. 67).
Lefebvre argues, and his mode of theorization demands, that the production of abstract space, the homogenization and fragmentation of social space, is never complete. Residuals of its opposite-nature, femininity, the everyday life, differences (Lefebvre, 2003a, p. 27)will always survive in the crevices and faults of abstraction. Some of these crevices and faults appear within what Lefebvre characterizes as the contradictions of space or "a dialectic of centrality" (Lefebvre, 1991b, p. 331). He thus furthers his conceptualization of the production of space by integrating his earlier thoughts on the increasingly tight urban fabric and urban centrality as he conceptualizes the general contradiction of space as the uneven development between centralities, or the concentration of the dominant practices and representations that structure social space as such, and the peripheralized spaces, such as suburbs and vacant spaces (Lefebvre, 1991b, p. 331), where residuals (nature, citizens) either are evicted or flee to-and where the dominant structuration of social space is cracking and thus open for new developments.

So, as Lefebvre 'transductively' pursuits the virtual possibility of the urban, which persists "and even intensify...[as the] inhabitants reconstitute centers, using places to restitute even derisory encounters" in spite of the destructive implosion of power and money (Lefebvre, 1996, p. 129), he moves away from the established centralities of the city and strong points of the state (Lefebvre, 2009b, pp. 117, 144) towards what he variously characterized as the 'fissures', 'chasms', 'cracks', 'crevices', 'voids', 'weak points' or just 'vacant spaces' of the city and social space (Lefebvre, 1969, p. 31, 1976, p. 120, 1991b, pp. 167, 264, 1996, pp. 129, 145, 156, 2009b, pp. 117, 144-145, 2014, p. 98).

\subsection{The Vague and Residual Significance of Diverted Spaces}

As his work on the production of space culminates around The Production of Space (Lefebvre, 1991b) and Towards an Architecture of Enjoyment (Lefebvre, 2014), Lefebvre perceives the diversion of vacant spaces as crucial to the ongoing "sociological transduction" performed by small groups pursuing the virtual and possible (Lefebvre, 2002, p. 117), towards new and concrete modes of production that transcend abstract space. The concept is explored over a few pages in The Production of Space in relation to a period of redevelopment in his local neighborhood in Paris, Les Halles. The abandoned physical structure of the former food market was gradually taken over by young groups in Paris in the late 1960s. For a couple of years, while awaiting the plans for its redevelopment, it was a hot spot of alternative activities never imagined by the architects, planners or politicians.

Lefebvre followed the developments in this "gathering-place and...scene of permanent festival...for the youth of Paris" (Lefebvre, 1991b, p. 167), but the dialectical pairs of concepts like abstract product versus 
oeuvre and the philosophically more canonized contradiction of domination versus appropriation could not really do the job of signifying their transductive character. Lefebvre perceived and sought a conceptualization of tendencies of something else, a residual beyond these dual contradictions. Lefebvre described Les Halles as "vacant, and susceptible of being diverted, reappropriated and put to a use quite different from its initial one" and deemed it "of great significance", since "[it] teach[es] us much about the production of new spaces" (Lefebvre, 1991b, p. 167). Les Halles was a window into the production of the opposite of abstraction: difference (Lefebvre, 1991b, p. 382).

However, despite its 'great significance', and despite his extensive reference elsewhere to terms of emptiness and in-betweenness as conducive of social change, Lefebvre never performs a thorough conceptual exercise, which could further ground the concept of diversion in his work or in the current social space of the city (for example in relation to the concept of transduction or the canonized triad of perceived, lived and conceived). It is an 'almost' concept, which in Lefebvre's political project means that it is either half complete or half failed. In a quotation that very symptomatically lacks somewhat in terminological, if not conceptual, precision regarding the distinction between appropriation and diversion, but of course without forgetting the concrete universal of production (here, the ability to produce one's own space as opposed to merely diverting the space of others), Lefebvre's epitaph for the concept of diverted space thus reads: "The goal and meaning of theoretical thinking is production rather than diversion. Diversion is in itself merely appropriation, not creationreappropriation which can call but a temporary halt to domination" (Lefebvre, 1991b, p. 168). It ends up as a reduced difference, "forced back into the system by constraint and violence" (Lefebvre, 1991b, p. 382).

In this way, Lefebvre is himself caught in the crossfire of an all too clear-cut contradictory conceptualization of a phenomenon, which, due to its 'vague' character exactly reveals the reductive character of the conceptualization and practice applied to it. So, diversion and vacant spaces are left by him as merely tactical, as insignificant residuals though deemed of great importance; even though they are concrete examples of inhabitants reconstituting centralities by gradually concentrating people, activities and meaning; even though the diversion might only be a philosophical conceptualization away from intensifying its appropriative ability and hereby taking the leap to the production of a space of its own. Lefebvre's leaving these phenomena as residuals has consequences for his own project and for the way the potentials of vacant spaces and their diversion are perceived today. Both Lefebvre's ambivalence towards the phenomenon and developments within and around vacant spaces of cities all over the world ever since have underlined the importance of this seemingly residual phenomenon for urban change.
In Section 3, we will pick up where he left his conjunction between sociological (practical) and conceptual (theoretical) transduction. We will do it in a conceptualizing narrative in which recent developments in Copenhagen will be unfolded through Lefebvre's concepts. We will further develop his thoughts, partly regarding the creation of new centralities through the concept of 'concentration' and partly regarding the gradual, transductive conjunction that occurs in the development of perceived (practical), lived, social, conceived (conceptual) and political associations in vague spaces; a process we term 'intensification'. In unfolding this urban perspective, our aim is both to further develop Lefebvre's urban critique and to critique the currently dominant, creative and critical perceptions of Lefebvre, of the city in general and of Copenhagen in particular.

\section{Contradictory Copenhagen: Urban Diversions Before, Between and Beyond Critique and Creative Co-Optation}

\subsection{Copenhagen: Generally Vacant and Susceptible of Being Diverted}

The economic, geographical and political restructuring of Copenhagen from the 1970's up until today has already been dealt with thoroughly (Andersen \& Jørgensen, 1995; Lund Hansen et al., 2001), but in order to place the narrative of the case and thus ground its conceptualization, a short introduction will be made in the following.

After centuries of constant growth, general processes of globalization and economic restructuring meant that Copenhagen went through decades of painful crisis, seeing industrial jobs, inhabitants and tax revenues fleeing to other parts of the country, Europe and the world in the 1970s and 1980s (Andersen \& Jørgensen, 1995). A physical consequence of this was that major parts of the capital were laid waste, especially along those means of transportation where industry developed up to the Second World War: the railway and the waterfront.

Therefore, ever since the 1970s, the question of creating economic growth, alleviating social consequences and the redevelopment of the gradually increased amount of vacant spaces of the Copenhagen waterfront had been on the agenda. A decision in the national government in 1989 to turn its attention towards revitalizing the geography and economy of the capital was accompanied by a general shift in the mode of urban policy towards a market-oriented form of entrepreneurialism. Several public-private-partnerships were created, and territorial masterplans were substituted by "Grand Projects" entailing infrastructural projects, cultural mega events and the development and sale of public properties (Andersen \& Jørgensen, 1995, p. 20; Bayliss, 2007; Gaardmand, 1993; Lund Hansen et al., 2001;). Thus, part of the attention from the government meant that the 
crisis-ridden, left-wing capital was forced to sell most of its properties (including almost 20,000 dwellings and attractive land at the harbor front (Andersen \& Jørgensen, 1995, p. 15)-hereby further opening the space of Copenhagen to market forces.

In this policy climate the question of vacant spaces reached a preliminary culmination, when in 1999 the Ministry of Cities and Housing launched a committee concerned with new methods of redevelopment of abandoned industrial spaces. Mainly based on the compact city-model, the concluding report suggested certain dispensations from general planning regulation and (as a consequence of the policy shift) the formation of publicprivate partnerships in order to speed up the revitalization of prioritized zones of redevelopment in cities (Committee of Business and Urban Policy, 2001, pp. 3, 16).

So, apart from the integration of policies of cultural planning, sparked by being the Cultural Capital of EU in 1996, a mega event organized in line with the thoughts of Charles Landry (Thomsen, 1999), the policy-network circling around the municipality of Copenhagen swiftly integrated these considerations regarding both spatial redevelopment and new forms of governance in its overall planning (Bisgaard, 2010; Desfor \& Jørgensen, 2004). New local plans (the basic, legal documents enabling redevelopment) were gradually created for the current and future redevelopment of the waterfront from industry to a much denser mix of housing and commercial functions. However, the urban subcultures of Copenhagen were also on the move regarding the 'reappropriation' of vague spaces.

The urban sub-cultures, of course, had already for decades noticed the potentials of abandoned spaces with a history of politically informed squatting from the popular 'slum stormers' of the 1970s (founding the diverted space, which later developed into the established, alternative, hippie centrality of 'Christiania') to the 'BZ'movement of the 1980s (with 'The Youth House' at their core). By the 1990s, however, the squatting culture had declined as it gradually lost the vital, diverted spaces that wore the imprint of and resonated with its development (Mikkelsen \& Karpantschof, 2001), and a new culture of diverting vague spaces was on the rise (Larsen \& Frandsen, 2014).

The new culture surrounding the vague spaces of the city gathered pace with the establishment of several informal harbor cafés around the turn of the millennium. They were all established in buildings abandoned by the harbor industry and were instrumental in the popular rediscovery of spaces of the city that was otherwise 'hidden in plain sight' and forgotten. But compared to earlier decades, the surge into the vague spaces had other implications.

From being very politically oriented towards general societal change or structural critiques of the distribution of housing possibilities in the 1970s and 1980sa political culture characterized as utopian (Dienel \& Schophaus, 2002) - the culture of diverting vague spaces in the 2000s displayed a marked skepticism towards both the way, society functioned and the explicit critique hereof. Hence, this topian rather than utopian culture was more interested in realizing the physical potential ready at hand in the vague spaces themselves through pragmatic negotiations with economic and political interests (Dienel \& Schophaus, 2002; Fezer \& Heyden, 2007 , p. 39). The vitalizing energy from the vague spaces of the city is thus first and foremost integrated in an aesthetic-sensuous rediscovery of the city-often with post-industrial litter of yesteryear, such as the empty warehouse structures and left-over building materials, as the main means of physical diversion. This disruptive phase of the informal culture of the city meant that it was extremely open and energetic in its integration and translation of current tendencies in Copenhagen into cultural expressions-and thus also, just as Lefebvre's concept of diversion, open towards both transduction and reduction. A significant example of the new urbanism early in this period is the scene, which developed in a small but centrally located spot in the harbor of Copenhagen, Krøyer's Place.

\subsection{First Wave of Diversions: Harbor Cafés and Proto-Creative Entrepreneurship}

For several centuries the central harbor was dotted by several so-called trading places of large mercantile companies along the waterfront. A major one of these was the Greenlandic Trading Place at Wilder's Island (Wilders $\varnothing$ ) in the historic Christianshavn neighborhood. Having been the hub for the trade with the North Atlantic for centuries, the trading company left for a more provincial location in the mid-1970s, and the historic warehouses became spatial left-overs for the following decades, leaving a dormant piece of prime real estate in the middle of the harbor facing the tourist magnet, $\mathrm{Ny}$ havn. In the late 1990s, while locals called their beloved island "The Sleeping Beauty", the property was deemed superfluous by its institutional owner and transferred to a recently formed public development company in order to develop and sell it on the real estate market along with other state-owned properties (Desfor \& Jørgensen, 2004). However, in the late 1990 s and early 2000s, the steadily rising real estate market was still not ripe for a redevelopment of the site. Seen ambivalently both as a "Dead Dog Space" and as a potential "Golden Egg Goose" by planners of the municipality and the property owners, the leading agents of a gradually forming policy-network regarding the redevelopment of the harbor was only in the early stages of preparing for the future (Larsen, 2007).

Then, in relation to a prospection for a possible film location in early 2001, a small group of entrepreneurial people discovered the obvious spatial potentials in the relative emptiness of a spot at Wilders $\varnothing$ called Krøyer's Place. The idea of a harbor café quickly entered their minds, and in a matter of weeks they got the tempo- 
rary lease from the public development company, the necessary permissions from the municipality and turned parts of two empty warehouses into Luftkastellet (literally 'the pipe dream'), which was characterized by one defining diversion: the landscaping of the quayside as a sandy beach. The plan was just to run the café over the summer, but the informal social arena of this urban sandbox and the historic warehouses made it such a huge success (named Café of the Year in 2001) that the temporary lease was prolonged several times. In the meantime, the café encouraged Copenhageners to meet not only over informal and yet expensive cups of latté, but also over different kinds of projects in the informal spaces. Gradually, the warehouses were filled with several sorts of entrepreneurs (clothing designers, graphic designers, video producers, an event bureau, a clothing outlet, a kayak club, a monthly culture magazine and so on), all making simple and gradual reorganizations of the spaces at hand with the typical "aesthetic register of the 'alternative culture"' (Carmo, Pattaroni, Piraud, \& Pedrazzini, 2014, p. 274): urban 'driftwood' such as pallets and containers and raw building materials such as wooden boards, plywood and plastic covers. One of the initiators thus described it as a place 'where the energy was let loose'.

Thus, the concentration of people and activities around the diverted space meant that it was on its way to becoming a centrality, which the public sphere of the city as a whole started to perceive as a defining part of a new 'self-made' and authentic form of urban development. Furthermore, the intensification of the diversionary culture-both the neo-tribal energy in its burgeoning social associations and the gradual, practical diversion and the cultural expressions in conjunction with it ("throwing sand on the floor" as a saying that implied informality, to mention just one of these expressions)meant that it was becoming a vortex with its own voice and representations.

However, some of the terms, which its practical concentration became a signified for in a hot summer of urban epiphanies in 2002, had been hanging in the air as more or less floating signifiers, at least since the 1990s: 'urban life' and 'experience'. In this way, Luftkastellet became an ambiguous icon of another way of redeveloping the harbor, which was otherwise undergoing a commercial redevelopment dominated by large cultural institutions, business headquarters and gradually also housing-all in very debated architectural styles (Desfor \& Jørgensen, 2004).

In the autumn of 2002, during a period of heated debate regarding the redevelopment of the harbor, the café was invited as an exponent of the informal perspective to participate in a panel meeting with other influential actors of Copenhagen in order to develop a new and constructive form of dialogue. Here the café further intensified the special energy of Krøyer's Place by conceiving itself in terms of a 'milieu breaker' in an otherwise languishing space and a 'communication bridge' between different actors in the city, and by doing it in the pub- lic domain it also intensified its political significance. Despite this fresh input, the meeting turned into a farce of destructive political antagonism through the power of a routine political de- and resubjectivation so symptomatic of the contemporaneous political climate in Copenhagen (Desfor \& Jørgensen, 2004).

However, the meeting not only, once again, affirmed disbelief in a constructive debate in Copenhagen. Through Luftkastellet's intervention, it also became an essential moment in the formation of a new and, in a radically democratic sense, political actor in Copenhagen. Thus, from its identity as fragments of a negatively 'subjectivated' crowd, another social association unfoldedunited negatively in an endeavor not to replicate the debating climate of Copenhagen in general and the atmosphere of that meeting in particular-but also positively by venturing towards the making of something else.

The group found some space in one of the warehouses in Luftkastellet at Krøyer's Place and, after refurbishing the premises during the spring of 2003, started experimenting with new ideas for harbor development and new ways of dialogue-one of the latter being to invite opposing interests to partake in an openly agitating and therefore agonistic, but also constructive, arena. One year of experimentation led to Supertanker having a keen eye for the constructive potential of informal urbanity-pursued through emerging terms about the 'unplanned', 'temporary interstices', 'pockets', 'cracks', 'pauses' and 'self-made spaces': a conceptual angle on the peculiar character of the place, which transduced the outspoken curiosity of the period and moved the practical reclamation of the empty warehouses beyond mere diversion and into the debate and discourse of the overall urban development, where the laboratory also challenged the way citizens were made to interact in debates. The tagline "vitalize the city and the debate concerning it" brought it all together. It took the vitality of this vague space and brought it further into the political arena. Thus, a gradually clearer critique of the conventional way of planning and debating the contemporaneous development of Copenhagen unfolded. With a new dialogical concept, Free Trial!, Supertanker thus helped a student organization organize a large event criticizing and reopening the otherwise antagonistic debate of the spring 2004 regarding the future of the alternative community of Christiania.

From the new social association of Supertanker, different, now more conceptualized aspects of the diversionary perspective on urbanity in self-made spaces and in dialogical processes thus gathered strength (an intensification of conceived associations) and both galvanized Krøyer's Place as an alternative centrality and took the first steps from here into a challenge of other, more established, practical and discursive spaces in the general, public domain of Copenhagen. And, as such, Supertanker evolved explicitly political aspects of its voluntary, social association within the diverted, vague space. The transductive exploration of the urban was gaining in strength. 
However, in the urban policy-networks of Copenhagen, new policies were about to enter the agenda and challenge this gradual intensification and concentration of the urban possibilities of the vague space at Krøyer's Place. One of these policies, the one about creative cities, had already been travelling through the academic and political circles of crisis-ridden societies for some decades-before its descent as a full-fledged floating signifier on Copenhagen.

\subsection{The Descent of the Creative Discourse on Copenhagen}

In the decades following the crises of the 1970's, countless post-industrializing urban regions in the global North started looking for a new economic base amidst regional growth discourses about flexible and small-scale producing, and locational and innovative advantages of regional clusters (Florida, Mellander, \& Adler, 2011). Among catch-phrases for the new economy like 'information', 'knowledge', 'service' and 'experience', thoughts of 'innovation' and 'creativity' gained a foothold, both in the North American context (Jacobs, 1986) and especially in the Scandinavian context (Andersson, 1985).

From this regional growth discourse, and in a political climate of critique towards state bureaucracy, the perception of creatively induced economic growth has unfolded in an urban context, not least through the work of Charles Landry and Franco Bianchini, which gained a foothold within urban policy during the 1990s and was benchmarked with a widely influential book (Landry, 2000). Canonized by Peter Hall (1998), creativity was globally exposed and gradually got more empirical bearings through the "formal model for urban growth" in Richard Florida's book The Rise of the Creative Class (Florida, 2002; Florida et al., 2011). Consequently, the 'fuzzy' concept of creativity became the buzzword of urban planning (Kunzmann, 2005) and has more or less dominated urban policy-making ever since-even canonized by the United Nations as a way to create a better world (UNDP, 2008).

The creative policy trickled down from the discursive sphere to a local, Danish context through a collaborative imagineering of the cross-border agglomeration of $\emptyset$ resund as a creative region conceptualized by the aforementioned Andersson and a local professor of regional economic geography (Matthiessen \& Andersson, 1993). Gradually, the policy entered government bodies and local "organizations of boosterism" (Lund Hansen et al., 2001 , p. 853). These early and rather general considerations were met with strong criticism from local exponents of another, internationally cultivated discourse.

\subsection{Neo-Marxist Critique of the Emerging Creative Governance of Copenhagen}

Just as the discourse of creative cities, a critique of urban development has evolved since the early 1970s within the primarily Anglo-American, Neo-Marxist academic sphere of influence. Having a vantage point in a critique of the political economy of capitalism, it has evolved in a dialectical relation to the debates regarding economic restructuring through analytic concepts such as 'restructuring', 'deindustrialization', 'reindustrialization', 'post-Fordism' and 'internationalization' (Brenner \& Theodore, 2005).

A crucial moment in the 'urbanization' of the classic Marxist critique was Henri Lefebvre's reference to urbanization as the second circuit of capital (Lefebvre, 2003a). The renowned Marxist geographer, David Harvey, and his students and colleagues in Anglo-American academia, has ever since unfolded the implications of this urban process under capitalism (Harvey, 1978) and its internal contradictions within the uneven development of urban areas between investment opportunities in underdeveloped urban areas, the social costs of the concomitant gentrification and sociospatial polarization (Smith, 1984, 1996), and the barriers to further capitalization that the spatial fixes of investments (such as buildings and infrastructure) represent (Harvey, 1980).

With Harvey's article on urban entrepreneurialism (Harvey, 1989), this perception entered the field of urban politics in a pathbreaking way. The alignment of urban planning with the needs of economic investment was conceptualized as a shift from the traditional managerialism of the Keynesian welfare state to more speculative policies. This policy was increasingly seen as a local expression of a shift to a 'free market'-sanctioning form of governance characterized with the buzzword 'neoliberalism' (Harvey, 2012; Peck, 2004). Today, this perception has evolved into an enormously influential critique of "neoliberal urbanism" (Brenner, Marcuse, \& Mayer, 2011; Brenner \& Theodore, 2005).

The critique of creative approaches to urban development looms large in the general, neo-Marxist critique of neoliberalist urbanism. Already in Harvey's seminal essay on urban entrepreneurialism, this policy is singled out. In this perspective the creative-city approach is seen, quite rightly, as part of entrepreneurial projects reinventing crisis-ridden cities in order to attract capital (Harvey, 1989). The critique, of course, is that the creative-city projects mostly benefit the well-to-do (Swyngedouw \& Kaïka, 2003). Maybe the most biting and, well, entertaining critique of the creative discourse is the one from Jamie Peck (2005), who perceives it as a "fast policy" of "seductive 'traveling truths", of "portable technocratic routines and replicable policy practices that are easily disembedded and deterritorialized from their centers of production" (Peck, 2005, p. 768).

This international critique is replicated in a Copenhagen context by several academics. As the creative policy emerges, the critique of the emerging entrepreneurialism of economic growth (Gaardmand, 1993) and flexible governance (Desfor \& Jørgensen, 2004) is supplemented. A very early and well-argued example of this is Lund Hansen et al.'s critique of 'creative Copenhagen' 
(2001). Apart from making distinctions within the creative curiosity between attempts, such as Peter Hall's, to understand the geographical aspects and the more pragmatic endeavors, such as Charles Landry's, into the development of toolkits for creative city-making "without critically examining possible social costs", their argument is focused on placing the new considerations of creative policy in Denmark and Copenhagen within the general "neo-liberal strategies" (Lund Hansen et al., 2001, pp. 852, 863). 'Creative Copenhagen', in short, comes down to "place-marketing", whose exclusive focus on growth both leads to and ignores "processes of gentrification ..., [which] entail the deportation of marginalized inner city residents who do not fit in the disneyesque 'creative city'" (Lund Hansen et al., 2001, pp. 852-853). Citing the newly appointed head of planning for his focus on improving the housing stock and thus preventing a mechanism, where Copenhagen gets "all the trash", Lund Hansen et al. conclude that "'[a]ll discourses have their silences'....and the blaring silence of the discourse on creative cities is that about social costs" (Lund Hansen et al., 2001, pp. 862-866).

At this point in time, in the early 2000s, the creative policy has not yet been practically implemented in plans and projects of Copenhagen, and, to be fair, Lund Hansen et al.'s argument is more a case of demonstrating the neo-liberal implications of an international discourse and the initial, discursive reproduction of this by local agents in the general, neo-liberalized context of Copenhagen (analyzed under heavy influence from the international, Neo-Marxist discourse), where the creative tenets would eventually be realized on ground in the following years. But the implementation of the tenets, and the implications of it, was just around the corner-to a certain extent confirming the skepticism of its NeoMarxist adversaries.

\subsection{Policy and Subculture: Urban Life, Creativity and Urban Deliberation}

Pursuing the orchestration of cultural and creative industries, there is a marked shift in policy from social to economic aims as the tenets of the creative city trickles down from the more general government policies to different local agencies of boosterism in Copenhagen (Bayliss, 2007, p. 896). The policy of creative cities enters the broader, public domain of Copenhagen in late 2002, as Richard Florida's book on creativity quickly comes to dominate the agenda of a city already reinventing its forgotten spaces and its sense of urban life. With the governing body of the region already replicating the main theses regarding tolerance and creative environments (Bayliss, 2007, p. 897), the municipality also gets in on the agenda. When heaping praise on the scene around Luftkastellet in early 2003, the Lord Mayor thus refers explicitly to it as an example of the string of "new creative milieux" (Mikkelsen, 2003), through which the city has to make a living in the future-throwing the tempt- ing "ambiguous polysemy" (Carmo et al., 2014, p. 274) of its free-floating and reductive signifiers onto a scene of disrupted energy looking for bearings.

Several representatives of the cultural scene and public servants repeat this creative message with a more or less direct reference to Florida-not least the aforementioned new head of planning who was also instrumental in the introduction of new forms of governance in the municipality (Bisgaard, 2010). And, as if following the creative manual of Florida, the American professor was invited to Copenhagen in the fall of 2003-maybe, as Peck puts it in his critique, for "the mayor and other civic leaders to appear on platforms, invariably in appropriately bohemian locations, with local creative entrepreneurs and arts activists" (Peck, 2005, p. 747). In any event, and as a sign of the energetic and double-edged openness in the disrupted, informal culture of Copenhagen, the entrepreneurs from Luftkastellet and Supertanker is directly involved in this visit as location managers at 'a bohemian location' in a newly established harbor café further out in the harbor. The municipality is in the early stages of formulating the first edition of a new form of communicative policy document, a 'planning strategy'and the imprint of Florida's tenets are clearly present. A preliminary document, adorned with a photo of the informal 'beach quay' in front of Luftkastellet, is focused on "the new business life", the creative businesses (Municipality of Copenhagen, 2004a), and the final strategy reads like an assignment in the implementation of Florida's tenets with its focus on creative businesses, urban life, talent, tolerance and deregulation to cater for the special needs of the creative (Municipality of Copenhagen, 2004b; Bayliss, 2007).

Just as the municipality, the encounter with Florida and the creative perspective on urban development, leaves its mark on Supertanker. In the otherwise inhibiting climate of functionalist planning in Copenhagen, the implicated governance innovation in the shift of focus both away from technological and educational infrastructure, as was the focus of traditional growth-oriented planning, and from a rigid planning regime as such, to the attention on the urban, human and cultural environment, was seen as creative winds of change. This meant that the tenets of the creative city perspective were seen as instrumental for the informal scene of cultural and economic entrepreneurship in Copenhagen.

So, Supertanker becomes a central part in the debate on creative urban development as they unfold their perception of the potentials of self-made spaces and urban development. Using their own intensified experiences from the new centrality of the diverted warehouses and their potential for all kinds of economic, cultural and political projects, Supertanker produced several smaller events, documents and formal hearings and policy-proposals on the topic. Both voicing an urban critique and testing the possibilities of 'cashing in' through the creative agenda without giving up its 'vague', autonomous position as a platform outside the system. 
As such, one of the events pitted a local exponent of the Neo-Marxist critique against the head of planning, whose call for 'the defense of the last, true urbanists' was put in perspective by his counterpart's claims about the social costs of, as it says in the critical article mentioned above, "the disneyesque 'creative city'" and the focus on attracting "new middle class' employees" through "luxury housing" (Lund Hansen et al., 2001, p. 853).

This critique and the conflict it pointed out here in the spring of 2004, would be more pertinent than anyone could imagine: At the same time as the creative policies, and the Neo-Marxist critique of it, descended on Copenhagen, and in the process pitting both transductive and reductive practices against each other, other plans of the local policy-network unfolded-with crucial consequences specifically for the gradually unfolding, informal centrality of Krøyer's Place, as well as for the political climate in Copenhagen in general.

\subsection{Politics as Usual: Sanctioning the Political Implications of Transduction}

During the spring of 2004, four years into the experiments of Luftkastellet and Supertanker and the gradually developing concentrations and intensifications, a newly booming real estate market (following a short period of stagnation, a steady rise in housing prices gathered pace and grew exponentially from 2003 to 2006; see, Dam, Hvolbøl, Pedersen, Sørensen, \& Thamsborg, 2011, p. 48) catches up with the diverted space at Krøyer's Placeand more concrete plans for urban development enter the stage. Backed by the municipality, the public development company proposes a luxury housing project in an expressionistic design for the location-confirming the skepticism within the general critique of creativity (Lund Hansen et al., 2001) and the more specific critique of the 'flexible governance' in the harbor redevelopment (Desfor \& Jørgensen, 2004) voiced earlier. A historically unique situation of agreement between left and right in the council, and between planners and developers, supporting a strong 'Yes' to the proposal, quickly and naturally subjectivated the general and especially the local public in the Christianshavn neighborhood as strong adversaries mobilizing around a just as clear and loud 'No'.

Somewhat taken by surprise, Supertanker and the scene at Luftkastellet struggled to find a fitting role in a new field of negotiation concerning the future of their own biotope. Instead of backing either one side or the other, Supertanker, based on a local initiative, tried to transduce the energy of the urban differences crystallized by the controversial proposal and develop an alternative vision process gathering and mediating the interests across yet another slowly but surely developing antagonistic dualism-but to no avail. Senior members of the policy-network, the public development company and the municipal planning authority, declined the possibility of participating in a process of deliberation for which Supertanker 'had no mandate'. As the diverted space of Krøyer's Place travelled from the fuzzy margins of planning debate to the discursive center of a heavily defined and reductively signifying conflict resembling the event that gave birth to Supertanker in the first place, the dialogical message was lost in a traditional battle over the summer of 2004 between pro and contra positions in relation to established planning categories such as building form, height and function. The antagonistic process, in this established and rigid mode of production of space, thus ran to the end of the line, leading to a controversial but final 'No' in the city council in the spring of 2005.

The destructive process and the, in the eyes of the policy-network, negative decision meant that the more political aspects of Supertanker's practice was blacklisted. Facilitating a deliberative process in the initiating moments of the local resistance did not resonate well with the perceptions of urban development processes in the policy-network within an urban industry (Naik \& Oldfield, 2010) described by one of the leading agents as a "small flock" (Lund Hansen et al., 2001, p. 855). There was a thin, but almost palpable line between reductive inclusion and excluded transduction in this 'flock', which was living through a veritable shock in the months and years after an episode that went down in modern history of Copenhagen under the name of Krøyer's Place-and Supertanker was made to feel this palpable line.

To make matters worse, the energy of the warehouses faded, as they were cleared and, later, in the summer of 2005, torn down (later to be sold to an international investor), just as the concentration and intensification of the informal centrality was reaching a point, where it, with its recent experiences in the explicitly political arena, could take a transductive leap to become a culture with a strong and clear conception of the production of an urban space in Copenhagen in its own right. Supertanker was left with no resonating space in which to further unfold their experiments. To quote Lefebvre: with the lack of "conjunction with a (spatial and signifying) social practice, the [locally diverted] concept of space [could no longer] take on its full meaning" (Lefebvre, 1991b, p. 137).

The energy of the property market in general also soon faded, as the local bubble of "skyrocketing house prices" burst in 2008 and the effects of the crisis in international financial markets had an enormous local impact in Copenhagen (Dam et al., 2011, p. 47). In the years following the battle in the public domain of Copenhagen regarding Krøyer's Place, yet another proposal for the site was taken off the table and the new, international property owner went bankrupt. Consequently, the site was not only vague, but a veritable tabula rasa for years to come.

As the political implications of the local, transductive culture was sanctioned by the urban industry, the general crisis in the market of urban development in Copenhagen only exacerbated the possibility of and need for the further evolution of more pragmatic, creative tools 
for urban growth. And these tools were gradually harnessed in the selfsame culture.

\subsection{Anchoring Policy, Reducing the Urban: Creative Zones, Temporary Use and Urban Truffle Pigs}

In 2004 , creativity as a means to create an economically sustainable development had become the core question in the, now formally adopted, planning strategy (Municipality of Copenhagen, 2004b). The following year, the policy-tool of 'creative zones', that is, "mixed industrial areas within the inner city...designated as suitable for further creative industry development" (Bayliss, 2007 , p. 898), came to designate a new level of detail in the local discourse (even being sanctioned in legally binding local plans for urban development in certain post-industrialized areas of the municipality). Simultaneously, within the diversionary subculture, parts of Supertanker were drawn gradually closer to the central policynetworks of Copenhagen. The experiences from the diversion of the vague space at Krøyer's Place was increasingly extracted from its resonance chamber (which, after the eviction, was now more signifying than spatial) and mobilized within an internationally-inspired and locally ever more dominant discourse of 'creative urban development' - thus hollowing out the autonomy of the otherwise intensified associations of the culture.

In the continued, mutually dependent development of the creative agenda within urban planning and the sub-cultures of diversion as well as the public in Copenhagen, much inspiration was taken from the development in other European metropolises such as Amsterdam and Berlin-relayed by the EU research project 'Urban Catalyst' among other sources. Just as in Copenhagen, the surge of sub-cultural energy in the new forms of topic diversion of vague spaces had been gradually harnessed in these cities into new tactical takes on urban regeneration, which more or less could be condensed in concepts of 'temporary use of urban fallows', which not only benefit the site but also the immediate surroundings, the general growth potentials in the creative industries of a city and the overall urban development (Bayliss, 2007, p. 889; Urban Catalyst, 2003). The difference, compared with the culture in Copenhagen, was the scale of the diversionary activities as well as their conceptual clarity-in short, their level of concentration and intensification-but also the operational and collaborative character of the tactics (vis-à-vis the policy-networks of the cities). It is in this reduced form that the energy of the sub-cultures of Amsterdam and Berlin flowed back not only to the level of urban planning, locally and internationally, but also to related sub-cultures in other cities, for example Copenhagen.

Through the knowledge of these European cultures of the temporary, Supertanker both took a leap in the understanding of its own heritage and further pursued the possibilities of getting the urban potentials in diverted space recognized with the economic agents as well as the planning authorities. This culminated in the spring of 2005 in another influential Free Trial!, gathering locals, creatives and a great number of people from the urban industry creating a manifesto on the theme of 'Cool Cash and Creativity' (Christrup, Hey, Larsen, \& Jørgensen, 2006). After this process, without a diverted space of their own to frame the conjunction of the gradually intensified associations, the vague culture bifurcated into complementary activities, still resonating with the diversionary culture from Krøyer's Place, albeit in a reduced and fragmented fashion: The more commercial parts of Supertanker, the entrepreneurs behind Luftkastellet, were in close and constant dialogue with varying parts of the policy-network regarding a relocation and repetition of the bustling urban life created at the café at Krøyer's Place. Another part sought to conceptualize the dialogical processes into a design business. Yet another part pursued the possibilities of combining its take on the urban in a less political way with the 'needs' of urban development as perceived by the urban industry, that is, along the lines of an equation. Through a zoological analogy, this equation came down to: 'urban fallows + urban truffle pigs = urban life' (Brandt, 2008). Yet another part integrated the creative, political and diversionary experiences as part of the academic curricular, through which both keeping and developing the integrity and political autonomy of the transductive culture, but within the abstract confines of a neo-liberalized knowledge institution without the direct presence in the urban development of a place in Copenhagen (Larsen, 2007).

With this reductive bifurcation, the first wave of diversion, having gone through an initial moment of diverting its own space at Krøyer's Place and consequent moments of transductive concentration and intensification, can be said to be concluded. The concluded wave has thus revealed both the possibilities of transducing the urban and the perils of reduction when the diversionary culture is deprived of its own space of conjunction, and hence exposed to more established practices and representations-be they creative or critical-which, on the other hand, signify the temporary surge of concentration and intensification within processes of government innovation and urban theorization, respectively. As the empty lot at Krøyer's Place was still awaiting its future destiny, Copenhagen experienced two further waves of diversion, influencing both transductive and reductive as well as critical and creative cultures in the process-and therefore also paving the way for the concluding phases of development at Krøyer's Place.

\subsection{Second Wave of Diversion: Negotiating Critique Between 'Hippies' and 'Politicians'}

The second wave of diversion sweeps Copenhagen in the wake of a serious plunge in the real estate market and the global financial crisis in the mid to late 2000s (Dam et al., 2011). It takes its energy both from the experiences of the first, disruptive wave surrounding the harbor cafés in 
general and from Luftkastellet/Supertanker in particular, as well as from another, more recent disruption on the more radical scene in the urban sub-culture, which unfolds in the aftermath of a very dramatic evacuation of The Youth House with subsequent riots in the spring of 2007. An avalanche of critique of society and support for The Youth House fills magazines, newspapers and streets in the following months (Bjerg, 2007)-all lauding the vague spaces as necessary for life and participation in the city. The activism culminates during the summer months of 2008, where The Free Commune of Refshalevej is realized (Bjerg, 2010; Kimouche \& Jensen, 2010), contributing to the mobilization of yet more culturally and politically experimenting and challenging groups in the diversion of a piece of road along Christiania. As the action is calmly and clinically closed down by police, the closelyknit groups move on to what, due to its character as an intensely diverted space 'of its own', comes to constitute the major hub of the next wave of diversion: The Candy Factory (Søberg \& Kimouche, 2011).

Founded as an underground club in a former candy production site months prior to the Free Commune of Refshalevej in 2008, the place quickly develops-partly due to the active intervention of a group of artists called Bureau Detours. The Candy Factory unfolds as an open and pulsating free space for creative, collective and uncommercial activity-and gradually intensifies its culture of diversion accordingly: supplementing the now established, Berlin-type of wasteland-aesthetics with a Gaudiesque play with tile and concrete and calling itself the largest sculpture in the city and expressing a culture of 'doing it together' as opposed to 'doing it yourself'. Within the urban sub-culture, this earns them the nickname 'the hippies' as opposed to the more explicit societal critique in the 'political' line of the older, more established Youth House. This distinction is manifested in the more selfcontained nature of the factory, focusing on its own, positive manifestation of alternative practices within its own, user-driven workshops and its increasingly popular concerts that acted as fulcrums for its urban concentration. Apart from a large public hearing (with the participation of several other 'free spaces' of Copenhagen) in the fall of 2012 discussing the pertinent question of 'liberty vs. equity' in the gentrifying city, the more explicitly political critique within the public domain emanates from other fragments of the radical culture surrounding the former Youth House and its geographical vicinity.

The umbrella organization 'openhagen' (demanding more social openness and inclusion in contemporary Copenhagen) is a significant example of this more political line. Established as a critique of cultural normalization, the annihilation of free spaces and gentrification (Hospital Prison University Radio, 2017), its activities culminated in several days of urban festival in the spring of 2010 bearing the name Undoing the City-not least focusing on dismantling neoliberal and creative representations of urban development. Mostly (in)famous for its final 'party', where a shopping street in the old core of Copenhagen was ravaged, the festival also communicated the problem of gentrification to a broader, radical audience, not least with the participation of some of the local exponents of the critique of neoliberalism in Copenhagen. Following up on the first wave of diversion, they later criticize the tendency of the "the urban 'truffle pigs"' - while having a critical potential and "without necessarily wanting to" - to "easily become strategic instruments in the neoliberal urban policy", arguing that "the instrumentalization of the 'creative class' ought to be a warning" (Larsen \& Lund Hansen, 2012, p. 144). They also direct a critical pun towards attempts at understanding these practices theoretically through Lefebvre by asking: "Was this what Henri Lefebvre had in mind four decades ago, when he formulated his vision of the right to the city?" (Larsen \& Lund Hansen, 2012, p. 144).

\subsection{The Third Wave of Diversion: A 'How-To'-Guide of Creative Co-Optation}

Despite the critical intent of the second wave, it also shows how strong the attraction of the creative discourse is. At a point in time, the explicitly critical, 'political' circles around the Youth House attempted to construct itself as a creative culture in a large hearing in order to sublimate its otherwise radical energy as a resource for mainstream society. And, though critical of commercial creativity and the creative policies of the municipality (Søberg \& Kimouche, 2011), the urban concentration of the collaborative congeniality at The Candy Factory cannot help but direct even more attention towards the general importance of vague spaces and their diversionan importance, which was discursively constructed in very specific terms in Copenhagen. Due to its discursive strength and omnipresence, the creative agenda regarding these zones thus picks up on this energy and gathers further pace. In the ever more popular attention, groups with a more positive inclination towards creativity enter the scene in explicit dialogue with a municipal policy in Copenhagen, which reaches yet another level of detail, as concepts of and policy tools like 'temporary use of vacant spaces' and a systematic quantification of the aim of increasing the level of urban life enters the planning discourse by way of an ever stronger attention to these themes within 'creatively' inclined parts of the 'small flock' of researchers, consultants and public servants within the urban industry of Copenhagen (Hausenberg, 2008; Municipality of Copenhagen, 2009a, 2009b; Pløger, 2008). With this tactical consolidation of the strategic discourse, it now reaches further out into the culture of diverting vague spaces in Copenhagengathering strength for the next wave of diversion, which develops as a concrete offshoot from the scene at The Candy Factory-and as a consequence of a perception within policy, planning and daily life of the vague spaces as the hearths of economically creative practices, which had been gradually ripening since the appearance of the harbor cafés. 
In the fall of 2010, just after the low point of a real estate market with housing prices diving by one third from mid-2006 to mid-2009 (Dam et al., 2011), the organization Givrum.nu establishes the PB43 in a former paint factory at Amager as a hub for the more formally organized and economically entrepreneurial parts of the urban subculture in Copenhagen under the catchy parole disclosed in a 'how-to'-guide for temporary redevelopment in a more pragmatic, 'creative' spirit: "Empty building + Givrum.nu = Creative Urban Development" (ToftJensen \& Andersen, 2012).

In spite of this formal vantage point dominated by floating signifiers of the creative discourse-thus, a textbook example of what Lefebvre would characterize as "induced difference", a reproducible product of abstract logic (Lefebvre, 1991b, p. 372)-the concrete diversion still fosters an intense, collective sense of space with the users, and PB43 gradually concentrates into the hub of a pragmatic form of diversionary culture. As time goes by, however, the new burgeoning centrality becomes the signified for the self-same floating signifiers with which it was founded. Thus, the scene here links urban phenomena such as participation, culture, art and experiences yet closer to representations and strategies of 'temporary', 'creative' and 'user-driven development'. This strategic discourse has thus had a great influence not only on the formal planning of urban development, but also on the most recent developments within underground culture and politics.

Furthermore, Givrum.nu draws their experiences from PB43 and, in part, The Candy Factory into annual conferences aimed at creating encounters between entrepreneurs and the urban industry under the overall theme of 'user-driven urban development' - in line with the inherent demand within the creative discourse for harnessing the untamed energies of the city in a socially 'useful' direction and without resonance with the more autonomous spaces of an alternative urbanism - as documented in a brief report on temporary use as a 'tool for growth' (Givrum.nu, 2016).

\subsection{Coming Full Circle: Krøyer's Place as a Concrete Abstraction of Urbanity}

With the second and third waves of diversion, the scene is now set for the concluding development of Krøyer's Place. As of 2011, the sub-prime instigated low point of the property market has been overtaken by the pull of the, creatively signified, urban hype and it now enters a phase of constant growth (with housing prices almost doubled in central Copenhagen from late 2011 to late 2017). Consequently, the informal centralities of the second and third waves of diversion, the vague spaces of the former candy factory and the former paint factory, has been caught up by urban development, with youth housing and self-storage facilities now adorning the sites. The new property owners at Krøyer's Place also sense the dawning possibilities and a new proposal for the site is developed. It is flanked by a public process of deliberation, which shows that the policy network has learned the lesson from the major conflict ten years before. A parallel process of cultural priming of the site likewise shows that the developers integrates the third wave of diversion, in which the now formalized expressions of diversion is integrated in the creative discourse and, thus, coopted by the established interests of the policy-network.

Financed by the landowner, the process of cultural priming is a curated performance and workshop event organized on-site at the cleared grounds of Krøyer's Place in spring 2013. Framed verbally by a name, Spaces-InBetween: The City Becoming, and a content depiction, "bringing life to the in-between using the energies of urban culture", the event thus referred to the contemporaneous floating signifiers regarding 'urban life', 'experiments' and 'the poetic life of the in-between spaces of the city' (Dome of Visions, 2013). It was hosted by a local curator from the performance scene, with international facilitators (Richard Sennett's Theatrum Mundi) and property owners without any reference whatsoever to-let alone sense of-neither the essential history of the place, the ongoing urban and conflictual transformation process nor the city's anomic, diversionary cultures. As such, the priming process was a textbook example of the aestheticization, or rather aestheticist reduction, of by-gone diversion "devoid of its political implications", also experienced in other European cities, where the link between the physical expression and "the project of everyday appropriation of the urban environment" is lost (Carmo et al., 2014, pp. 274, 281). Rather than building on the temporarily intensified associations of these cultures, the process merely performs a discursive and harnessing construction in resonance with the contemporary floating signifiers of creativity in Copenhagen. A very clear and essential example of the consequences, when vague and concrete urbanisms lose their chambers of resonance within which a gradually stronger transductive conjunction between vague representations and practices can unfold.

And so, the development comes full circle at Krøyer's Place. Today, neither the first and second waves of urban and political diversions, nor the creative sublimations of its culture are anywhere to be seen on the site, now fully redeveloped, or rather, concretely abstracted, that is, reductively produced according to partial aspects abstracted from the urban. Then again, this is not completely true. Along the walls of the luxury housing, now straddling the quays, high-quality and specially designed replicas of the typical pallets of the earlier waves of diversion has been placed, in order to signify some of the urban vitality of yesteryear-yet, like the verbal buzz of the creative discourse, with only a floating and abstract relation to the processes and materials of the original diversions that had an altogether different perception of the urban incarnated as a mere virtual possibility. 


\section{Unearthing the Urban Residuals: Going Through the Vague Spaces, Beyond the Blind Fields}

\subsection{Affirmation of Established Truths}

"Anomic groups construct heterotopic spaces, which are eventually reclaimed by the dominant praxis" (Lefebvre, 2003a, p. 129). More or less homologous to his quote about diverted space, cited above in Subsection 2.3., this assertion of Lefebvre's from The Urban Revolution could also be the epitaph of the culture of diversion active in Copenhagen during the last decades. But in line with the conceptualization of Lefebvre, it should not be read as an epitaph, but rather as yet another small but significant moment in the ongoing differentiation of production, of the production of space, lived out by urbanites of Copenhagen. However, now that the reality of these moments of the ongoing production of space has been recognized, the question is how the lived experience of them should be conceptualized and hereby related to, rather than integrated in, other, currently dominant practices or perceptions of urban change.

The case narrative affirms the common-sense perception of the recent history of Krøyer's Place as a history of high-profile antagonism regarding a proposal for a high-rise project in the central part of the Copenhagen harbor. It also clearly shows the general implementation of the creative city discourse within the dominant policynetwork of Copenhagen since the late 1990s and that it has gone hand in hand with a general neoliberalization of Copenhagen in the decades since the late 1980sas already explicitly stated by agents within the policynetwork (Bisgaard, 2010) as well as by exponents of the critique of neoliberalism and others (Bayliss, 2007; Desfor \& Jørgensen, 2004; Lund Hansen et al., 2001).

\subsection{Supplement to Established Truths}

The case narrative supplements these statements with a perspective from the subcultural scene, which shows that not only urban policy and the general public but also much of the subculture of diversion in Copenhagen perceive urban development through the lenses of creativity. The critical perception is strongest behind the comforting walls of academia and currently only find limited resonance in the social space of Copenhagen, for example within left-leaning pockets of subculture, due to a process of co-optation of large parts of the diversionary culture by the dominant networks of the city-just as experienced in other major cities of diversion, such as Berlin (Fezer \& Heyden, 2007), Amsterdam (Uitermark, 2004), Brussels (Moyersoen, 2010), Geneva, Lisbon and Ljubljana (Carmo et al., 2014).

However, instead of merely going into tactical concepts regarding architectural practice, aesthetic participation, social movements, or, for that matter, the overly generalizing deductions regarding the failure of the diversionary cultures, as in conventional Marxist critique, the narrative integrates more strategic concepts from the urban philosophy of Lefebvre-most importantly the concepts of 'the urban', 'transduction', 'reduction', 'diversion' and, as further developments of Lefebvrean terms, 'vague space', 'concentration' and 'intensification'. It does so in order to explicate a general critique from another angle. While referring to the workings of policynetworks, subcultures and academia within the major contradiction of creativity and critique, there is another important distinction, which needs to be conceptualized regarding the development in Copenhagen. As dominant perceptions, we will argue, creativity and critique are related in a mutual construction of opposing poles that act reductively towards another perception of and practice in Copenhagen, that is, the urban. The way they act towards gradually intensifying phenomena, such as vague spaces and cultures of diversion, affirm this.

\subsection{Critique of Reductive Perceptions and a Window onto Urban Possibilities}

In the narrative, we have constructed creativity and critique as two discursive perceptions of urban change that have descended onto Copenhagen from their respective, international spheres of development to act out their contradiction in a proxy struggle on foreign terrain. In the following, we will take the argument from the case and pursue the struggle of the dominant contradictions, floating back to their "native soil" (Lefebvre, 2003a, p. 28) of international (mostly Anglo-American) discourse.

The contradictory perspectives of creativity and critique are comparable with Lefebvre's contradiction between domination and appropriation, but they do not in any way fit perfectly. Thus, there are certain affinities between the two perspectives as well. In fact, they are both chained to the capitalist mode of production. They are both critical of the (local) state. They highlight the urban as the level of opportunity and/or struggle regarding the necessary restructuring of the economy, as a primary means of a creative economy or as the arena in which to critique what is perceived as the secondary circuit of capital. And last, exponents of both camps are paradoxically, but quite tellingly, partly inspired by Lefebvre's critique of the abstract production of space.

Many interpreters of Lefebvre focus on his call for 'the right to the city' as the participation of citizens in the creation of the city as a collective oeuvre-a call sometimes scathingly labelled as romantic by some of the more orthodox, Marxist scholars (Huchzermeyer, 2013). It is due to this 'creative' vein in his critique of abstract space and the state that Lefebvre at irregular intervals figures in arguments for creativity. One of the finest examples is the work of Lehtovuori, whose critique of abstract urban planning in defense of the vitality of urban life and what he characterizes as the 'weak places' of the city has the 'unconcealing', 'weak' and 'poetic' thinking of Heidegger, Benjamin and, not least, Lefebvre's urban and spatial work as some of its major foundations 
(Lehtovuori, 2000, 2005). Lehtovuori, who contributed to the influential Urban Catalyst project mentioned above, has integrated this critique in a thorough study of the possibilities in and challenges of informality and temporary uses for a bottom-up creative city policy (Lehtovuori \& Ruoppila, 2012). And here the paradox between 'weak thinking' about 'weak places' and 'phenomena' arises. Even though the sense is clearly a very acute bottomup understanding of urban phenomena, and the philosophical grounding matches it, the level of strategic policy (thinking about the weak as 'temporary' and 'creative') is left untouched. So, the means may be bottomup, whereas the aims remain top-down. Lefebvre has a word for this, and that is 'co-optation'.

The critical perspective is, as shown above, focused on Lefebvre's strategic critique of the planetary and global circulation of capital-also heeding Lefebvre's call for the right to the city (Brenner, 2017; Harvey, 2012). A major inspiration in the development of Harvey's pathbreaking critique of capitalist urbanization, Lefebvre's critique is, as noted above, central for the contemporary critique of neoliberalism. Apart from Harvey, Neil Smith $(1984,1996)$ and Neil Brenner are major exponents of the integration of Lefebvre in such a critique.

The depth and breadth of Brenner's integration of Lefebvre in his critique of neoliberalism (Brenner \& Theodore, 2002) and the "new state spaces" (Brenner, 2004 ) is more or less unrivalled today. Mostly moving in the policy formation surrounding the different layers of the state, Brenner recently delved into the musings of the 'tactical urbanisms' that have evolved from the informal cultures of temporary use and the subcultures of cities in general (Brenner, 2017). With these "immediate, 'acupunctural' modes of intervention" that promote "a grassroots, participatory, hands-on, do-it-yourself vision of urban restructuring" (Brenner, 2017, p. 131), he says, one straddles the painful border between political critique and co-optation (Brenner, 2017, p. 145). However, even though he finds examples of tactical interventions and their visions of cities as "a commons, a space of continuous, collective appropriation and transformation by its users", he does not leave conceptual room for the urban possibilities in this, but instead finds that the activities in what he terms "interstitial spaces" merely coexist "with neoliberal urbanism in a relationship that is neither symbiotic, parasitic, nor destructive" (Brenner, 2017 , p. 133). As it typically is for the critical perspective, the major problem for Brenner (who is paradoxically referring to Lefebvre's extremely autonomist thought of autogestion as a counterpoint) is that tactical urbanism "[resist] and [reject] any movement toward institutionalization" (Brenner, 2017, p. 144) and consequently is more or less open towards or even "bolster neoliberal urbanism" (Brenner, 2017, p. 132). The homology between this argument and the kind and overbearing critique of 'the truffle pigs' by local exponents of the critical perception in Copenhagen shown above is clear.
As Lefebvre's thoughts move across the line of demarcation between the two contradictory perspectives on urban change, it becomes clear that they also constitute a common pole in a different contradiction. While both camps highlight the urban as the level of opportunity and/or struggle, they miss out on the pivotal and autonomous character of this level in Lefebvre's critique. As shown, whether it is a means of creative development or a secondary circuit of capital, it is a mere tactical level for the proxy struggle between the two camps. Both are political arguments that make claims on behalf of the urban, that claim to be urban, but neither of them will lend the urban any autonomy. The creative perspective integrates the concentrating energy of informal cultures before they gain a cultural intensity of their own. Likewise, the critical perspective already has a ready-made representation of strategic politics, which leaves no room for the urban to develop a politics of its own-labeling tactical attempts as class adversarial, revisionist or naïve well before they develop a voice of their own. Their relation to the urban is ambivalent at best, directly reductive at worst.

Whereas the creative perspective is rather uncritical vis-à-vis the economic growth paradigm or at least can be criticized for being depoliticized by ignoring the economic and bureaucratic interests in the city, which clears it from further responsibilities regarding a sober interpretation of Lefebvre, the critical perception of urban change is so deeply entrenched in Marxist theory that its take on and use of Lefebvre as well as the urban adjective ought to be more informed. But when it comes to the critique of neoliberalism it is locked on a target, neoliberal urbanization, which only has the urban as a means, and the critique of neoliberalism acts towards the urban accordingly.

This is very clearly a case of "dominant critiques of neoliberalism [travelling] beyond the sites of [their] epistemological production" (Baptista, 2013, p. 590). As this critique left the primary circuit of capital it should have followed suit with Lefebvre and widened its perception accordingly (Lefebvre, 1991a, pp. 102-103), instead of extending "to the urban domain the principles" of reductive productivism, to paraphrase Peck's critique of the creative discourse (Peck, 2005, p. 764). Lefebvre and his "open theory of the space of political economy" has been reductively integrated in a "closed theory of the political economy of space" (Charnock, 2010) with only scarce recognition of anything else than actually existing neoliberalism -least of all the possibilities of the urban. The conventional Marxist critique of Neoliberalism focuses on a concrete abstraction of the broader phenomenon of production. What Lefebvre attempts is to show the coherent differentiation of the concrete universal of production into practices of concentration that act as practical bases of both the urban and the capitalist economy and the discourses, which reproduces its basic functioning. Single-mindedly hunting down the concrete abstractions of capitalism leads to a critique being 
haunted by them-while reducing the possibility and reality of the urban in the process.

As has already been shown above, Lefebvre himself was acutely aware of the reductive tendency even with his Marxist peers-and Marx himself (Lefebvre, 1991a, pp. 102-103). His critique of the reduction of the urban is maybe most to the point in The Urban Revolution, the selfsame book that presented his thoughts on urbanization as part of the secondary circuit of capital. Here he likens the industrial gaze on the urban with the enigma of the black box: "They know what goes in, are amazed at what comes out, but have no idea what takes place inside" (Lefebvre, 2003a, p. 28). In other words, the urban is a "blind field": "We focus attentively on the new field, the urban, but we see it with eyes, with concepts, that were shaped by the practices and theories of industrialization, [which] is therefore reductive of the emerging reality" (Lefebvre, 2003a, p. 29).

This is exactly the case of the creative and critical gaze on diversions of vague spaces. Diversionary practices unfold in vague spaces of the city that, due to their vagueness and per definition, correspond to blind fields in the established discourses. Consequently, vague but nevertheless coherent practices of concentration and intensification are pulled apart, abstracted from their vague context and reductively signified by floating signifiers working overtime to construct some sort of representational coherency far away from their own native soil. So, all discourses have their silences, yes, and if the discourses of creativity and critique have one, it is paradoxically that of the urban.

As the presentation of Lefebvre's thought above may have demonstrated, his work was very much concerned with the conceptual and therefore political autonomy of the urban, in that "it assumes that the city (the urban center) has been a place for creation and not simply a result....It stipulates that the urban can become 'objective', that is, creation and creator, meaning and goal" (Lefebvre, 2003a, p. 28). The urban is a primary moment of production, a further differentiation of the concrete universal and thus an attempt at a transcending conceptualization. So, as inhabitants constantly "reconstitute centres, using places to restitute even derisory encounters" (Lefebvre, 1996, p. 129)-or divert vague spaces for the same purposes - the gradual intensification of new, aesthetic and political, senses of the urban from out of the concentration of people and practices is no less real than the economic circuit, in which exchangeable abstractions of this concentration circulates. This concentration is not just an economic possibility of creative venture for entrepreneurs or a risk of economic dispossession for marginalized locals, but also a possibility of ever new moments of the urban, which need to be lived out and conceptualized with adherence to the "intimate link between politics and aesthetics" (Carmo et al., 2014, p. 279); between critique and creativity, in order to revitalize and transcend the current, abstract perception of the production of space-and revitalize the dormant residuals of the urban.

\section{Conflict of Interests}

The authors declare no conflict of interest.

\section{References}

Andersen, H. T., \& Jørgensen, J. (1995). City profile: Copenhagen. City, 12(1), 13-22.

Andersson, A. E. (1985). Kreativitet-storstadens framtid: En bok om Stockholm. Stockholm: Prisma.

Baptista, I. (2013). The travels of critiques of neoliberalism: Urban experiences from the "borderlands". Urban Geography, 34(5), 590-611.

Bayliss, D. (2007). The rise of the creative city: Culture and creativity in Copenhagen. European Planning Studies, 15(7), 889-903.

Bisgaard, H. (2010). Københavns genrejsning 1990-2010. København: Bogværket.

Bjerg, P. (2007) Pink punk i kampen for Københavns fristeder. Citadel, 2007(February), 30.

Bjerg, P. (2010) Opbyggerne på Refshalevej. In K. Wikstrøm \& H. Hallgrimsdottir (Eds.), Get Lost: Et Atlas over det (u)mulige København. Copenhagen: Dansk Arkitekturcenter.

Brandt, J. (2008). Urbane Brakzoner og Trøffelsvin. Copenhagen: Supertanker.

Brenner, N. (2004). New state spaces: Urban governance and the rescaling of statehood. Oxford: Oxford University Press

Brenner, N. (2017). Is tactical urbanism an alternative to neoliberal urbanism? In N. Brenner (Ed.), Critique of urbanization: Selected essays (pp. 128-146). Basel: Birkhäuser.

Brenner, N., Marcuse, P., \& Mayer, M. (2011). Cities for people, not for profit: Critical urban theory and the right to the city. London: Routledge.

Brenner, N., \& Theodore, N. (2002). Cities and the geographies of "actually existing neoliberalism". Antipode, 34(3), 349-379.

Brenner, N., \& Theodore, N. (2005). Neoliberalism and the urban condition. City, 9(1), 101-107.

Carmo, L., Pattaroni, L., Piraud, M. \& Pedrazzini, Y. (2014). Creativity without critique: An inquiry into the aestheticization of the alternative culture. In P. Soares Neves, and D. Freitas Simoñes (Eds.), Lisbon Street Art and Urban Creativity - 2014 International Conference (pp. 274-281). Lisbon, Urbancreativity.org.

Charnock, G. (2010). Challenging new state spatialities: The open marxism of Henri Lefebvre. Antipode, 42(5), 1279-1303.

Christrup, T., Hey, E. S., Larsen, J. L., \& Jørgensen, S. Q. (2006). Hvidbog om Kroner og Kreativitet. Copenhagen: Forlaget Supertanker.

Committee of Business and Urban Policy. (2001). Betænkning fra erhvervs-og bypolitisk udvalg. Copenhagen: Ministry of Business and Housing.

Dam, N. A., Hvolbøl, T. S., Pedersen, E. H., Sørensen, P. B., \& Thamsborg, S. H. (2011). The housing bubble 
that burst: Can house prices be explained? And can their fluctuations be dampened? (Monetary Review, 1st Quarter 2011, Part 1, pp. 47-70).

Desfor, G., \& Jørgensen, J. (2004). Flexible urban governance: The case of Copenhagen's recent waterfront development. European Planning Studies, 12(4), 479-496.

Dienel, H. L., \& Schophaus, M. (2002). Temporary use of urban wastelands and the development of youth cultures (Working Paper). Berlin: Urban Catalysts.

Dome of Visions. (2013). Spaces-in-between: The city becoming. Dome of Visions. Retrieved from http:// domeofvisions.dk/spaces-in-between-the-city-becom ing-byens-mellemrum-byens-tilblivelse

Fezer, J., \& Heyden, M. (2007). The ambivalence of participation and situational urbanism. Atelier d'Architecture Autogeree (Eds.), Urban/act: A handbook for alternative practice (pp. 329-335). Montrouge: AAA-Preprav.

Florida, R. (2002). The rise of the creative class - and how it's transforming work, leisure, community and everyday life. New York, NY: Basic Books.

Florida, R., Mellander, C., \& Adler, P. (2011). The creative city and the creative class (Working Paper). Toronto: Martin Prosperity Institute.

Gaardmand, A. (1993). Dansk byplanlægning: 19381992. Copenhagen: Arkitektens Forlag.

Givrum.nu. (2016). Midlertidighed som byudviklingsstrategi-et værktøj til vækst. Copenhagen: Ministry for Foreigners, Integration and Housing.

Hall, P. G. (1998). Cities in civilization: Culture, technology, and urban order. London: Weidenfeld \& Nicolson.

Harvey, D. (1978). The urban process under capitalism: A framework for analysis. International Journal of Urban and Regional Research, 2(1/3), 101-131.

Harvey, D. (1980). The limits to capital. Oxford: Blackwell.

Harvey, D. (1989). From managerialism to entrepreneurialism: The transformation in urban governance in late capitalism. Geografiska Annaler: Series B, Human Geography, 71(1), 3-17.

Harvey, D. (2012). Rebel cities: From the right to the city to the urban revolution. Brooklyn, NY: Verso.

Hausenberg. (2008). Midlertidige aktiviteter som værktøj i byudviklingen. Århus: Municipality of Århus.

Hospital Prison University Radio. (2017). Openhagen om bykampe inden for de sidste 10 år [Radio podcast]. Retrieved from https://soundcloud.com/hospitalprison universityradio/openhagen-om-bykampe-inden-forde-sidste-10-ar-11092017

Huchzermeyer, M. (2013). Humanism, creativity and rights: Invoking Henri Lefebvre's right to the city in the tension presented by informal settlements in South Africa today. Inaugural lecture at the School of Architecture and Planning, University of the Witwatersrand. Retrieved from https://www.wits.ac.za/ media/news-migration/files/Inaugural\%20lecture.pdf Jacobs, J. (1986). Cities and the wealth of nations: Princi- ples of economic life. Harmondsworth: Penguin Books. Kimouche, D., \& Jensen, S. S. (2010) Jeg har kun et ord at sige om Refshalevej. In K. Wikstrøm \& H. Hallgrimsdottir (Eds.), Get Lost: Et atlas over det (u)mulige København (pp. 98-99). Copenhagen: Dansk Arkitekturcenter.

Koefoed, E. (2017). Punktum på Krøyers Plads: Luksusliv møder kajliv. Magasinet KBH. Retrieved from https:// www.magasinetkbh.dk/indhold/kroeyers-plads

Kunzmann, K. R. (2005). Creativity in planning: A fuzzy concept? Zürich: Netzwerk Stadt und Landschaft, ETH Zürich.

Landry, C. (2000). The creative city: A toolkit for urban innovators. Hoboken, NJ: Taylor and Francis.

Larsen, H. G., \& Lund Hansen, A. (2012). Retten til byen. In J. Andersen, M. Freudendal-Pedersen, L. Koefoed, \& J. Larsen (Eds.), Byen i bevægelse: Mobilitetpolitik-performativitet (pp. 131-147). Frederiksberg: Roskilde Universitetsforlag.

Larsen, J. L. (2007). Politisk urbanitet: Projekter, planer og protester $i$ Københavns havn (PhD. thesis). Roskilde: Roskilde University.

Larsen, J. L. (2014). Lefebvrean vaguenesses: Going beyond diversion in the production of new spaces. In Ł. Stanek, C. Schmid, \& A. Moravánszky (Eds.), Urban revolution now: Henri Lefebvre in social research and architecture (pp. 319-339). Aldershot: Ashgate Publishing.

Larsen, J. L., \& Frandsen, M. S. (2014). Situationens urbanisme. Kultur \& Klasse, 43(118), 155-173.

Lefebvre, H. (1969). The explosion: From Nanterre to the summit. Paris: Monthly Review Press.

Lefebvre, H. (1976). The survival of capitalism: Reproduction of the relations of production. New York, NY: St. Martin's Press.

Lefebvre, H. (1991a). Critique of everyday life. New York, NY: Verso.

Lefebvre, H. (1991b). The production of space. Oxford: Blackwell.

Lefebvre, H. (1995). Introduction to modernity. New York, NY: Verso.

Lefebvre, H. (1996). Writings on cities. Oxford: Blackwell.

Lefebvre, H. (2002). Critique of everyday life (Volume II). New York, NY: Verso.

Lefebvre, H. (2003a). The urban revolution. Minneapolis, $\mathrm{MN}$ : University of Minnesota Press.

Lefebvre, H. (2003b). Hegel, Marx, Nietzsche. In S. Elden, E. Lebas, \& E. Kofman (Eds.), Key writings. New York, NY: Continuum.

Lefebvre, H. (2009a). Dialectical materialism. Minneapolis, $\mathrm{MN}$ : University of Minnesota Press.

Lefebvre, H. (2009b). The state in the modern world. In N. Brenner \& S. Elden (Eds.), State, space, world: Selected essays (pp. 95-123). Minneapolis, MN: University of Minnesota Press.

Lefebvre, H. (2014). Towards an architecture of enjoyment. Minneapolis, MN: University of Minnesota Press.

Lefebvre, H. (2016). Metaphilosophy. London: Verso. 
Lehtovuori, P. (2000). Weak places: Thoughts on strengthening soft phenomena. City, 4(3), 398-415.

Lehtovuori, P. (2005). Experience and conflict (Doctoral dissertation). Helsinki: The Technical University of Helsinki.

Lehtovuori, P., \& Ruoppila, S. (2012). Temporary uses as means of experimental urban planning. Serbian Architectural Journal, 4(1), 29-54.

Lund Hansen, A., Andersen, H. T., \& Clark, E. (2001). Creative Copenhagen: Globalization, urban governance and social change. European Planning Studies, 9(7), 851-869.

Matthiessen, C. W., \& Andersson, Å. E. (1993). Kreativitet, integration og vækst i Øresundsregionen. In Udvikling i Øresundsregionen (pp. 17-19). København: Hovedstadsområdets Trafikselskab.

Mikkelsen, J. K. (2003). Borgmesterens København. Politiken, 2003(January).

Mikkelsen, F., \& Karpantschof, R. (2001). Youth as a political movement: Development of the squatters' and autonomous movement in Copenhagen. International Journal of Urban and Regional Research, 25(3), 593-608.

Moyersoen, J. (2010). Autonomy and inclusive urban governance. A case of glocal action: City Mine(d) in Brussels. In F. Moulaert, E. Swyngedouw, F. Martinelli, \& S. Gonzalez (Eds.), Can neighbourhoods save the city? Community development and social innovation (pp. 153-167). Abingdon: Routledge.

Municipality of Copenhagen. (2004a). Fremtidens København og københavnere-visioner og initiativer fra kommuneplanstrategi 2004. Copenhagen: Municipality of Copenhagen.

Municipality of Copenhagen. (2004b). Fremtidens København og københavnere-kommuneplanstrategi 2004. Copenhagen: Municipality of Copenhagen.

Municipality of Copenhagen. (2009a). Muligheder for midlertidige anvendelser. Copenhagen: Municipality of Copenhagen.

Municipality of Copenhagen. (2009b). Metropol for mennesker. Copenhagen: Municipality of Copenhagen.

Naik, D., \& Oldfield, T. (2010). The urban industry and its post-critical condition. In D. Naik \& T. Oldfield (Eds.), Critical cities. Volume 2: Ideas, knowledge and agitation from emerging urbanists (pp. 3-27). London: Myrdle Court Press.

Peck, J. (2004). Geography and public policy: Constructions of neoliberalism. Progress in Human Geography, 28(3), 392-405.

Peck, J. (2005). Struggling with the creative class. International Journal of Urban and Regional Research, 29(4), 740-770.

Pløger, J. (2008). Midlertidige Byrum. In H. Juul \& F. Frost (Eds.), Byens rum-det fremmede $i$ det kendte (pp. 52-61). Copenhagen: Arkitekturforlaget B.

Smith, N. (1984). Uneven development: Nature, capital, and the production of space. Oxford: Blackwell.

Smith, N. (1996). The new urban frontier: Gentrification and the revanchist city. London: Routledge.

Søberg, M., \& Kimouche, D. (2011). Om Frizoner i Dansk Planlægning. Dansk Sociologi, 22(1), 111-121.

Stanek, L. (2008). Space as concrete abstraction: Hegel, Marx, and modern urbanism in Henri Lefebvre. In K. Goonewardena, S. Kipfer, R. Milgrom, \& C. Schmid (Eds.), Space, difference, everyday life: Henri Lefebvre and radical politics (pp. 62-79). London: Routledge.

Swyngedouw, E., \& Kaïka, M. (2003). The making of "glocal" urban modernities. City, 7(1), 5-21.

Thomsen, L. (1999). Storbyens epokemonumenter, ruiner, livskræfter og rytmer: Skitser til en teoretisk og empirisk analyse af Københavnsregionens forskellige urbaniteter: Centerrapport. Copenhagen: KACTUS.

Toft-Jensen, M., \& Andersen, S. (2012). Byen bliver tilen urban håndbog. Copenhagen: Forlaget PB43.

Uitermark, J. (2004). The co-optation of squatters in Amsterdam and the emergence of a movement meritocracy: A critical reply to Pruijt. International Journal of Urban and Regional Research, 28(3), 687-698.

UNDP. (2008). Creative economy report. New York, NY: UNDP.

Urban Catalyst. (2003). Urban Catalysts-Synthesis. Unpublished report. Retrieved from www.templace. com/think-pool/attach/download/1_UC_finalR_syn thesis007b.pdf?object_id=4272\&attachment_id=4276

\section{About the Authors}

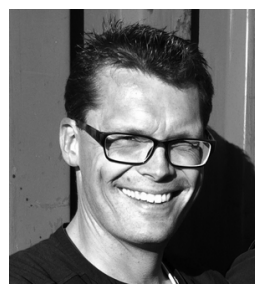

Jan Lilliendahl Larsen has studied and participated in urban development and politics in the past two decades. He completed his PhD in 2008 with a dissertation based primarily on Henri Lefebvre. The empirical part of this work contributed to the creation in 2003 of the Copenhagen-based group of urbanists, Supertanker, with whom he has been working as researcher, teacher and practicing urbanist. He has authored several essays, reports and articles on the current state of urbanity in Copenhagen and internationally.

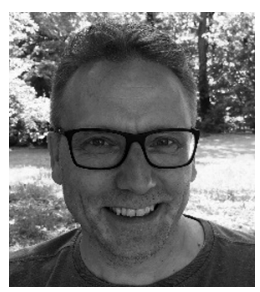

Jens Brandt is an architect (MAA) based in Copenhagen and Berlin, at Weissensee Academy of Art. His field of work can be described as a cross-connection between the build environment and public sphere or in short "the urban". He is teaching at the School of Architecture, Tampere, Finland. Co-founder of Supertanker, a Copenhagen based network working on the borders between action research, process design and urban development. 